\title{
WILLOW AND ROCK PTARMIGAN MONITORING IN RUSSIA: AN HISTORIC OVERVIEW
}

\author{
Roald Potapov ${ }^{1}$ and Eugene Potapov ${ }^{2}$

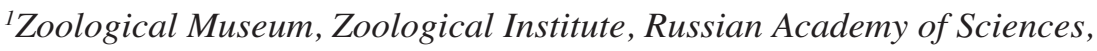 \\ Universitetskaya nab 1, St. Petersburg, Russia. \\ E-mail: Roald.Potapov@gmail.com \\ ${ }^{2}$ Bryn Athyn College, Bryn Athyn, PA 19009, USA. \\ E-mail: eugenepotapov@gmail.com
}

\begin{abstract}
The Willow Ptarmigan (Lagopus lagopus) and Rock Ptarmigan (L. muta) are among the most numerous species of ptarmigan in Russia. Their ranges cover most of the tundra zone and the alpine zone of some mountains. Willow Ptarmigan also breed in the bogs found in forest and forest-steppe zones of Russia and adjacent countries. During the Pleistocene, their ranges were much larger and extended as far south as $40^{\circ} \mathrm{N}$, and in the Holocene, the ranges of both species experienced several episodes of shrinkage and expansion. Range shrinkage is currently evident in many areas of Russia; for example, several southern enclaves recently ceased to exist. The density of Willow Ptarmigan is substantial in the tundra zone, and the current advancement of shrubs to the north, evident throughout the Arctic, makes the habitat even more hospitable. In general, the effect of global warming on habitat appears beneficial for ptarmigan in the northern Palearctic. Current global climate predictions suggest that snow cover depth will be decreasing in the European part of Russia, and increasing in northeast Asia in the coming decade. This means that overwintering conditions for ptarmigan would be somewhat favorable in the European north because shrub parts would be more accessible. Deeper snow predicted for northeast Asia might cover most of the shrubs and limit the numbers of ptarmigan there. Ptarmigan were monitored in various localities throughout their range in Russia, but these efforts came to an end in the early 1990s with the cessation of the fur trade and the demise of the monitoring agencies. New restructured agencies have no monitoring schemes in place, or they exist only on paper and are not supported by funds and trained personnel. Received 1 March 2011, accepted 31 May 2011.
\end{abstract}

Potapov, R., AND E. Potapov. 2011. Willow and Rock Ptarmigan monitoring in Russia: An historic overview. Pages 213-228 in R. T. Watson, T. J. Cade, M. Fuller, G. Hunt, and E. Potapov (Eds.). Gyrfalcons and Ptarmigan in a Changing World, Volume II. The Peregrine Fund, Boise, Idaho, USA. http://dx.doi.org/10.4080/gpcw.2011.0221

Key words: Abundance, distribution, Willow Ptarmigan, Rock Ptarmigan, Russia, subspecies. 
THE LAGOPUS PTARMIGAN have been an important food source for people dwelling in the vast spaces of Eurasia since early Paleolithic times. During the early stages of the Industrial Revolution, ptarmigan were continuously seen in the markets of large cities in Russia. In the days of the USSR, Lagopus ptarmigan were harvested commercially in many places, and in the second half of the $20^{\text {th }}$ Century were monitored in several locations. Technically this monitoring is in place now, but poor training of personnel as well as a lack of funding make this monitoring scheme highly inaccurate. In addition, the majority of reports are scattered across a collection of papers, and are not indexed by abstracting companies. The purpose of this paper is to provide a brief summary of the Lagopus ptarmigan monitoring effort throughout Russia from these reports and other sources.

\section{EARLY HISTORY OF LAGOPUS PTARMIGAN IN RUSSIA}

The earliest fossils of ptarmigan were found in Southwest Europe (Poland and Bulgaria), and were dated as 3.1-4.2 million years ago (Bochenski 1991, Boev 1995). Within Russia, as well as in other sites of Eurasia, the paleontological evidence was dated from much later periods. The more easterly a finding is located, the earlier the date (Potapov et al. 2003). The remains of ptarmigan are most common in the layers of the late Pleistocene. By the end of the Pleistocene, ptarmigan reached the eastern fringes of the Palearctic, and then spread into North America. Because of a plethora of latePleistocene findings, it is possible to conclude that Willow Ptarmigan (L. lagopus), and to a lesser degree Rock Ptarmigan (L. muta), were abundant in the tundra-steppe landscape. The latter was spreading across the entire northern part of the Palearctic from the Atlantic to the Pacific. Almost every Paleolithic, Mesolithic and Neolithic archeological site contains a fair number of ptarmigan bones. The most favorable times for ptarmigan were the last two glaciations, known as Riss and Würm. The ptarmigan distribution was at its maximum, stretching from the Atlantic to the Pacific, and south to the Iberian, Appenine and Crimean Peninsulas. At the time there were no statistical differences between the fossil bones of Willow and Rock Ptarmigan throughout this entire range. The first study which managed to separate Willow from Rock Ptarmigan was carried out in Britain (Stewart 2000) and the separation dated back to Britain 450,000 BP. In all other sites up to the end of the Pleistocene, the differentiation between Willow and Rock Ptarmigan was and still is difficult.

The end of the Pleistocene and the beginning of the warmer Holocene period was caused by abrupt changes in the global climate. In a relatively short time, the climate caused a gigantic transformation of fairly uniform tundra-steppe into climatically differentiated biomes. From the west to the east, a new forest zone, soon to be a boreal forest biome, cut the tundra-steppe zone apart. The southern belt of the grasslands transformed into the steppe and forest-steppe biomes. Many species of the tundra-steppe formed disjunct ranges on both the southern and northern parts of the boreal forest, while others survived either on the northern or southern side of the boreal forest. For some species, the newly formed biome was fatal. For Willow Ptarmigan, this process forced the formation of four types of habitat adaptations for raised bogs, moors and river valleys, forest-steppe, and mountainous habitats. The latter, usually fenced by the forest belt below, as well as isolated enclaves in the southern fringes of their former range, are the direct descendants of their ancestral forms living together with the mammoth megafauna. Massive orogenesis elevated these relict habitat areas up to $1000 \mathrm{~m}$ or more asl, where they are still preserved in the alpine and sub-alpine zones of mountains of the southern Palearctic. Rock Ptarmigan have not survived in the flat forest-tundra steppe, but only in those areas of mountains isolated by vast areas of forested plains, or, as in Western Siberia, on semi-isolated or interconnected mountain tops. 
All these processes, which happened from the end of the Pleistocene until now, affected the distribution of both species. Most importantly, the ranges shrank. The first to split was the range of the Rock Ptarmigan, a species most adapted to a cold climate and hilly landscapes. The largest enclaves of this species are located in the most northern regions of the Northern Hemisphere: northeastern Asia and the northern part of North America. The third block of the previously continuous range is in Greenland. Here, Rock Ptarmigan were forced to survive on the fringes of the Greenland icesheet. The fourth are the isolates in the Arctic and Atlantic Oceans: Iceland, the British Isles, Svalbard, the Kola Peninsula and the Northern Urals. And finally, the southern-most group of isolates survived in Eurasia associated with the Pyrenees, Alps, to some extent the mountains of Kamchatka, Chukotka, Yakutia, and Japan, and Central Asian mountains: Altay, Sayan, Tarbagatai, and Khangai. In the north, the survival of Rock Ptarmigan is limited by the cold (Pleistocene-like) climate, and in the south, by the same Pleistocene-like climate on elevated mountains. The Rock Ptarmigan subspecies living in the Kuril Islands, Commander Islands and the Aleutians are very interesting isolates. Previously these islands were mountain ranges bordering Beringia. The islands in the Arctic Ocean with a flat landscape (Wrangel and Novosibirskie islands) do not have Rock Ptarmigan. So far, there are no big changes in the range of the Rock Ptarmigan in the Palearctic that can be linked to climate change as a result of global warming.

The range of Willow Ptarmigan is much bigger and has a relatively smaller number of isolates. It stretches across the continental plains northwards from $50^{\circ} \mathrm{N}$ latitude in Eurasia and 52$54^{\circ} \mathrm{N}$ in North America. The main part of its range is located within Russia, occupying all of the biomes: tundra, forest-tundra, taiga, forest-steppe and sub-alpine zones of Siberia and north-east Asia. If, at the end of the Pleistocene, the range occupied almost all of Europe, by the end of the Holocene it had shrunk significantly in the forest and foreststeppe zone, and the western border started to move east. There were a number of reasons for such a change: global warming, as well as increasing pressure from humans, most notably manifested in deforestation and converting lands in forest and forest-steppe zones into agriculture. After prehistoric times, the species ceased to exist in Ukraine, East Prussia, Poland, Lithuania and a larger part of Byelorussia. The species is dramatically waning in numbers in the current western parts of the range: Estonia, Pskov, Leningrad, Novgorod and Smolensk districts of the Russian Federation. In the 1950s-80s, the decline was mostly driven by a directive to convert raised bogs into arable lands, and/or peat extraction. No attention was given to the fact that these bogs sustain many species, such as Willow Ptarmigan, Western Capercaillie (Tetrao urogallus), Blackgrouse (Lyrurus tetrix), many migratory waterfowl, and maintain water balance or large drainage areas. The mild winters of 1990-2008 were devastating for this species. The white winter plumage of the Willow Ptarmigan was visible for large distances in periods without snow. Byelorussian ornithologists were first to note their visibility while counting game animals from helicopters. Unfortunately, in the majority of cases they were recording fresh kills, mostly by Goshawks (Accipiter gentilis) and Golden Eagles (Aquila chrysaetos). Currently the number of Willow Ptarmigan has gone down in the diet of these raptors. For example in the diet of the Golden Eagle the proportion of Willow Ptarmigan went from $2.3 \%$ in 1972-84 to $0.2 \%$ in 1985-2002 (Ivanovskiy and Kovalenok 2002).

Recent winters (2009-2011) were cold, without significant thaw periods, and had enough snow. This offers hope that the numbers of Willow Ptarmigan might start to increase. However there is a need for several such cold and snowy winters. It is not plausible that these cold winters will avert the eastward movement of the western border of the species' range. 


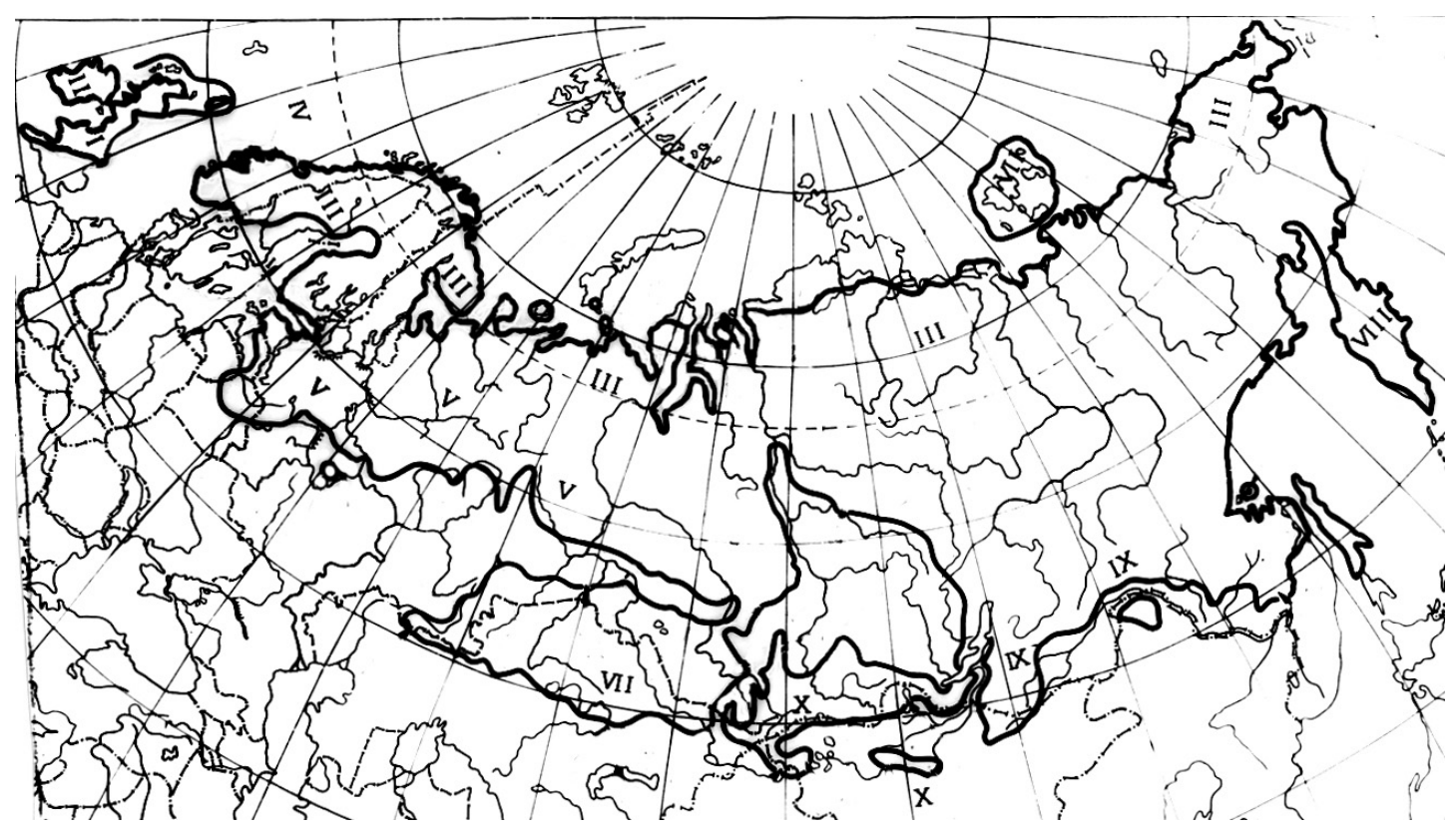

Figure 1. Range of Willow Ptarmigan in Palearctic (from Potapov 1985 with changes and additions). Numbers denote subspecies: I - L. I. scoticus, II - L. I. hibernicus, III - L. I. lagopus, IV - L. I. variegatus, V-IV - L. I. pallasi, VI - L. I. major, VII - L. I. kamchatkensis, VIII - L. I. serebrowsky, IX - L. I. brevirostis.

Abundant paleontological records do not allow even an approximate estimate of the density of the Willow and Rock Ptarmigan in pre-historic times. Only one thing is definite: that early dwellers of Eurasia were eating ptarmigan on a regular basis. It took about 10,000 years of evolution of the human civilization before it was plausible to monitor resources in nature. The counts became economically feasible, as well as useful. Large concentrations of humans in cities needed resources which exceeded those of small rural settlements. Commercial activities and an improved infrastructure (communications, roads, etc.) caused an increase of exploitation of natural resources.

In Russia, the first reliable data on the number and distribution of ptarmigan appeared from the end of the $19^{\text {th }}$ Century, and were mostly from the European part of the country. The numbers of the ptarmigan were determined by rule of thumb and usually given as "very abundant," "abundant," "common," and "rare" (Menzbier
1902, Sabaneev, 1902). More accurate counts were used from the 1920's. By the end of the $20^{\text {th }}$ Century, the Russian Federation had a functioning department for the conservation and development of the game resources. It had the Control-Analytical Center for the Game Animals and their habitats. One of the branches of this center is the Stage Game Counts Service. In the years 2000-02, this service made an attempt to make a standardized All-Russia Winter Game Survey (ARWGS) following the methods of Kuzyakin et al. (1990). The counts were carried out by the rangers, who were not properly trained, and tended to overestimate. Besides, many of them were not able to tell the difference between the Black-billed Capercaillie (Tetrao parvirostris) and Western Capercaillie, and most importantly, the Rock Ptarmigan from the Willow Ptarmigan. In the regions where only one species occurred, the results of the survey had great value. For the regions where both species occurred, we had to rely on the data from old literature. Ptarmigan were part of this 
Table 1. Density of Willow Ptarmigan in different Tundra areas, given in individuals per $10 \mathrm{~km}^{2}$, unless stated differently.

\begin{tabular}{|c|c|c|c|c|}
\hline Place & Year & Season & Birds per 10 km² $^{2}$ & Reference \\
\hline Bolshezemelskaya Tundra, North & 1939 & August & $181-422$ & Skrobov 1968 \\
\hline Bolshezemelskaya Tundra, South & 1939 & Aug, Sept & $650-2149$ & Skrobov 1968 \\
\hline Bolshezemelskaya Tundra, South & 1940 & May & $29-162$ & Skrobov 1968 \\
\hline Malosemelskaya Tundra & 1938 & Spring & $444-660$ & Mikheev 1948 \\
\hline Malosemelskaya Tundra, 67ㅇN & 1985 & Spring & 66 & Voronin 1995 \\
\hline Timanskaya Tundra & 1950 & June & 200-300 nests per 10 km² & Mikheev 1952 \\
\hline Yamal, North & 1989-94 & Spring & 206-350, average 286 & Tarasov 1995 \\
\hline Taimyr peninsula, shrub tundra 69-73ㅇN & $\begin{array}{l}1965 \\
1966 \\
1967 \\
1968\end{array}$ & $\begin{array}{l}\text { June } \\
\text { June } \\
\text { June } \\
\text { June }\end{array}$ & $\begin{array}{l}20 \\
32 \\
35 \\
15\end{array}$ & $\begin{array}{l}\text { Pavlov } 1975 \\
\text { Pavlov } 1975 \\
\text { Pavlov } 1975 \\
\text { Pavlov } 1975\end{array}$ \\
\hline Taimyr, Dudypta estuary, 72ㅇN & $\begin{array}{l}1960-62 \\
1963\end{array}$ & $\begin{array}{l}\text { Summer } \\
\text { Summer }\end{array}$ & $\begin{array}{l}\text { 120-140 pairs } \\
20-30 \text { pairs }\end{array}$ & $\begin{array}{l}\text { Krechmar } 1966 \\
\text { Krechmar } 1966\end{array}$ \\
\hline Taimyr, Pura lakes, 73ㅇN & 1965 & August & 55 broods & \\
\hline Taimyr, Pura lakes, 73ㅇN & 1967 & August & 70 & \\
\hline Taimyr, Mokritto Lake, 73ㅇN & 1968 & Spring & 30 pairs & Pavlov 1975 \\
\hline Novosibirskie Islands, Kotelniy Island & 1968 & March-April & 15 & \\
\hline Novosibirskie Islands, Lyakhovskiy Island & 1968 & March-April & 5 & Kishinskiy 1975 \\
\hline Khromo-Indigirka lowlands, Yakutia, 70-72º N & 1961 & Spring & 74 & Perfiliev 1975 \\
\hline Khromo-Indigirka lowlands, Yakutia, 70-72N & 1961 & Fall & 180 & Perfiliev 1975 \\
\hline Khromo-Indigirka lowlands, Yakutia, 70-72ㅇN & 1962 & Spring & 46 & Perfiliev 1975 \\
\hline Anabar, Yakutia & $1962-64$ & Spring & 200-320 pairs & Uspenskiy 1965 \\
\hline Koryak Mountains & 1960 & June & 250 pairs & \\
\hline Kamchatka tundra & $1965-67$ & Spring & 20 pairs & Gizenko 1968 \\
\hline Parapol depression, Kamchatka & 1976 & Summer & $30-110$ pairs & Lobkov 1986 \\
\hline
\end{tabular}

survey, and some transects recorded good numbers (Mezhnev 2000, 2002). Below we provide the density and numbers available to date by species and by different biological zones.

\section{Willow Ptarmigan (Lagopus lagopus L.)}

Tundra and Forest-tundra.-The northern boundary of this zone is set by the Arctic Ocean, the southern boundary is set by the timberline. In general Willow Ptarmigan are very abundant here, especially in the shrub sub- zone, in all the tundra areas from Kola to the Chukchee Peninsula. Willow Ptarmigan populations have a cyclic pattern in many places, but it appears that the cycles are not synchronous across the continents.

Kola Peninsula, Pasvik Nature Reserve. In the period 1993-2007, the total number of individuals seen on $10 \mathrm{~km}$ of transect reached a maximum (>5 individuals) in 1994, 1999, and 2001 , an average number (3 individuals) in 2004 and 2005; and a minimum ( $<1$ individu- 
als) in $1997,2002,2006$. There was $4-5$ year period between the absolute minima (Khlebosolov et al. 2007).

Kolguev Island $\left(5020 \mathrm{~km}^{2}\right)$, c. $75 \mathrm{~km}$ north of the Malozemelskaya Tundra. This island supports a very high density of Willow Ptarmigan (94-219 birds per km²) (Kurvitts et al. 2009). All Willow Ptarmigan move to the mainland in the fall. Local people bag about 1000 individuals per fall (Kondratiev 2006).

Nesting is reported from the entire Bolshezemelskaya Tundra. Fall numbers were estimated not less than 5 million. Only $20 \%$ were harvested by commercial hunters (1962-65). The numerical estimates are given in Table 1 .

Overall numbers of the Willow Ptarmigan in the Khroma-Indigirka tundras were estimated at 200,000 birds. Similar extrapolations for the Alaseya Tundra, Yakutia, for roughly the same area was given as 22,000 birds (Perfiliev 1975).

The density of Willow Ptarmigan in the Kolyma Tundras was studied in the 1970s1980s by Andreev (1988). He concluded that the ptarmigan population there has a 10 -year cycle governed by the production of 1-2 year twigs by the dominant shrub (Salix pulchra, $S$. glauca and $S$. kolymnensis). The density was measured by area occupied by territorial cocks. It was as low as 2.3 ha per territorial male in the peak years to 69 ha per territorial male during low density years. The peaks were reported in various regions of the Kolyma plain in 1980-81 and 1987, and a depression was reported in 1979.

Northern Taiga.- The data on density of Willow Ptarmigan in various regions of the Northern Boreal Forest (Taiga) is given in Table 2. In general, the densities of this species were much lower than in the tundra zone. The estimated total number of Willow Ptarmigan was given for the Sverdlovsk District (area c. 194,800 $\mathrm{km}^{2}$ ) as 17.5 to 25 thousand individuals (Romanov 1975). Western Siberia (up to $62^{\circ} \mathrm{N}$ ) had an estimated total number of 300-800 thousand individuals by the end of a typical summer, with fluctuations in density from 0.5 to 6.0 individuals per $\mathrm{km}^{2}$. In winter the total number of birds in this region increased 1.5 times because of an influx of birds arriving from the foresttundra subzone (Vartapetov 1998).

In Eastern Siberia, Willow Ptarmigan are rather common in bogs and sparse forests. In Yakutia, the best habitats for this species are in the lake hollows (Yakutian name: alas) covered with shrubs, sparse larch tree forest and vast areas of bogs. The numbers fluctuate, but the nature of these fluctuations is not properly understood. In the Far East, Willow Ptarmigan concentrate along river valleys where they find willow shrub. In Kamchatka, Willow Ptarmigan also occur in the coastal plains covered with Siberian Dwarf Pine (Pinus pumila). The density in these regions is very low (1-2 pairs per $\mathrm{km}^{2}$ ) (Kishninskiy 1975).

Southern Taiga.-The southern taiga subzone is occupied by the Middle-Russian subspecies of Willow Ptarmigan (L. l. pallasi Portenko 1972). It is distributed from the southern timber-line to c. $64^{\circ} \mathrm{N}$ (Potapov 1985). In contrast to the tundra and north taiga ptarmigan, this subspecies does not have significant seasonal movements; it is sedentary.

In the Pskov District, Willow Ptarmigan survived only in some isolated upland bogs. The surveys of 1997-98 estimated that the total number of this species in the district did not exceed 500 individuals (Fetisov et al. 1999).

In 2005-2010, Willow Ptarmigan almost disappeared in the Leningrad District. Perhaps a few pairs (1-2 per $10 \mathrm{~km}^{2}$ ) survived on upland bogs in the east of the District. It was listed in the Red Data Book of the Leningrad District (Potapov 2004). A similar situation exists in Byelorussia, where only a handful of reports from the northern part of the country exist and the species is listed in the Red Data Book of Byelorussia (Red Data Book 2006). It ceased 
Table 2. Density of Willow Ptarmigan in different parts of the Northern Taiga, given in individuals per $10 \mathrm{~km}^{2}$, unless stated differently.

\begin{tabular}{|c|c|c|c|c|}
\hline Place & Year & Season & Birds per 10 km² & Reference \\
\hline Karelia, North & $1957-64$ & & $31-67$ & Ivanter 1974 \\
\hline Karelia, South & $1957-64$ & & $18-22$ & Ivanter 1974 \\
\hline Karelia & 1960-70 & Winter & 1.7-82.6, average 24.3 & Ivanter 1974 \\
\hline Karelia & 1960 & Winter & $8.3-8.5$ & Karpovich 1963 \\
\hline Archangelsk District & 1960s & Winter & $10.8-14.7$ & Karpovich 1963 \\
\hline Komi Republic & $1960 s$ & Winter & $4.9-13.4$ & Karpovich 1963 \\
\hline Komi, Navishera River, 63NN & 1963-65 & Fall & $4-28$ & Sevastianov 1974 \\
\hline $\begin{array}{l}\text { Komi } \\
\text { in Voronin } 1995\end{array}$ & $1950-53$ & Winter & 48-300 & Maslov 1972, cited \\
\hline Komi, Mezen River 64-65№N & 1973 & Fall & 40 & Voronin 1995 \\
\hline Komi, Mezen River 64-65№N & & Spring & 18 & Voronin 1995 \\
\hline Komi, Vym' River & & Fall & $9.0-51.1$ & Voronin 1995 \\
\hline Komi, Vym' River & & Spring & $19.4-42.6$ & Voronin 1995 \\
\hline Northern Ural mountains & $1954-57$ & Summer & $1-1.1$ & Romanov 1975 \\
\hline Larch forests, western Putoran, 69N & $\begin{array}{l}1958-59 \\
1964\end{array}$ & Summer & 40-80 pairs & Krechmar 1966 \\
\hline Eastern Siberia & $1960 s$ & Summer & $6-63$ & $\begin{array}{l}\text { Syrocheckovskiy } \\
\text { and Rogacheva } \\
1968\end{array}$ \\
\hline Evenkia, Kataramb lakes & 1955 & August & $5-145$ & $\begin{array}{l}\text { Fedosenko and } \\
\text { Belozerov } 1968\end{array}$ \\
\hline Yakutia, Forest zone & \multicolumn{2}{|c|}{ 1960-70s Fall } & 80 & Perfiliev 1975 \\
\hline Yakutia, Forest zone & \multirow{2}{*}{\multicolumn{2}{|c|}{ 1960-70s Summer }} & $4-6$ & Perfiliev 1975 \\
\hline Kamchatka & & & $10-20$ & Kishinskiy 1975 \\
\hline
\end{tabular}

to exist in Mordovia, Chuvashia, Udmurtia, Mari-El, Ryasan and Tula Districts, and is almost extinct in the Moscow District (Romanov and Kozlova 2001). The situation was alarming even in earlier periods, when local hunters unanimously were citing the disappearance of this species. There were attempts to re-introduce the bird into Moscow, Leningrad, Yaroslavl, and Vladimir districts. In 1960, there were 2893 birds released there. (Romanov and Kozlova 2001). The re-introduction efforts failed because of poor preparation and lack of basic feasibility studies.
At the beginning of the 1980s, the southern border of the subspecies distribution crossed Smolensk, Moscow, Vladimir, Nizhniy Novgorod and Perm Districts up to the Urals. The standardized All-Russia Winter Game Surveys from 2000-2002 (Mezhnev 2002) did not record a single individual of this species in the Smolensk, Moscow, Vladimir, or Nizhniy Novgorod Districts. This species is impossible to miss on the snow as it makes unmistakable tracks. Therefore, the southern boundary of this subspecies' range is not currently known, but it has moved north since the 1980s. In the Perm District, the counts in 2000-2002 
Table 3. Density of Willow Ptarmigan in different parts of the Southern Taiga, given in individuals per 10 $\mathrm{km}^{2}$, unless stated differently.

\begin{tabular}{lllll}
\hline Place & Year & Season & Birds per $\mathbf{1 0} \mathbf{~ k m}^{\mathbf{2}}$ & Reference \\
\hline Leningrad District & $1866-1909$ & Spring & 15 & Rodionov 1969 \\
Leningrad District & 1949 & Summer & 16 birds on $1.5 \mathrm{~km}^{2}$ bog & R. Potapov, unpublished data \\
Leningrad District & 1960 & Summer & 3.3 broods & Rodionov 1969 \\
\hline
\end{tabular}

Table 4. Numbers of Willow Ptarmigan in the Western Siberian Districts recorded during the All-Russia Winter Game Counts 2000-2002 (Mezhnev 2002) and their overall density (individuals per 10 km²).

\begin{tabular}{lccc}
\hline Total number/density & $\mathbf{2 0 0 0}$ & $\mathbf{2 0 0 1}$ & $\mathbf{2 0 0 2}$ \\
\hline Kurgan District & $14,700 / 2.1$ & $21,900 / 3.1$ & $19,300 / 2.7$ \\
Tumen' District & $28,400 / 0.2$ & $24,100 / 0.2$ & $15,900 / 0.1$ \\
Omsk District & $82,900 / 5.9$ & $61,000 / 4.3$ & $67,000 / 4.7$ \\
Novosibirsk District & $76,500 / 4.3$ & $75,400 / 4.2$ & $56,900 / 3.2$ \\
\hline
\end{tabular}

recorded 25.2, 21.9 and 24.8 thousand individuals (Mezhnev 2002).

Currently there is a propagation project in the Kerzhanets State Nature Reserve, Nizhniy Novgorod District. In 2009, five birds raised in captivity were released within the reserve (Korshunova and Korshunov 2010).

Central Urals and Western Siberia.-The southern timberline crosses the Ural Mountain Ridge at c. $59^{\circ} 40^{\prime} \mathrm{N}$. The density of Willow Ptarmigan here is very low and during the breeding season is 1 or rarely $3-5$ individuals per $10 \mathrm{~km}^{2}$. In the $1970 \mathrm{~s}$, the total summer numbers of Willow Ptarmigan in the taiga zone $\left(85,000 \mathrm{~km}^{2}\right)$ of the Sverdlovsk District (total $194,307 \mathrm{~km}^{2}$ ) was $17.5-20$ thousand individuals (Danilov 1975). In the All-Russian Winter Survey (ARWS) in 2000, 2001, 2002 this figure was $80.9,171.2$ and 159.7 thousand individuals respectively (Mezhnev 2002). This large difference in numbers may be explained by the influx of migratory ptarmigan coming from the tundra zone in winter.

There is no data on the numbers of Willow Ptarmigan in the southern taiga subzone. In
Western Siberia, there is a large area between the taiga and forest-steppe which does not have Willow Ptarmigan. In the narrowest place the gap is 100-120 km (Danilov 1975). In contrast, the abundance of bogs between the $\mathrm{Ob}$ and Irtysh Rivers suggests that a high density of ptarmigan could occur here. There were only winter counts done in the area in 196467 , which recorded $1.5-50$ individuals per 10 $\mathrm{km}^{2}$ (Gyngazov and Shubin 1968). The number of Willow Ptarmigan recorded during the AllRussia Winter Game Counts 2000-2002 (Mezhnev 2002) in Western Siberian Districts are provided in Table 4.

Eastern Siberia.-This area has a very different type of southern taiga subzone. A lack of upland bogs, presence of permafrost-underlain lake depressions (alas) covered with shrub and grass vegetation, and less dense forest favors Willow Ptarmigan. The nominate subspecies lives here in an ultra-continental climate (Dfd, Dwd in Köppen-Geiger classification, meaning dry and relatively hot summers, and dry and extremely cold in winter (Peel et al. 2007). The numbers here fluctuate out of sync with various other regions, and the mechanism 
behind these fluctuations is not well understood (Isaev 2011 in this volume).

Amur River Regions.-Neither the distribution nor biology of the local population of Willow Ptarmigan has been studied here, but it is here where the southeastern boundary of this species' range in Eurasia is located. The range included lowlands of the Amur River estuary (Evron, Udyl, Kizi lake depressions). There are no breeding records further south from here, but there are some winter records (Potapov 1985). At the end of the $19^{\text {th }}$ Century, the numbers here were enough to harvest ptarmigan commercially, but now the species' density is extremely low. In the bogs of the Udyl lake depression in 1968, there were 10 pairs per $10 \mathrm{~km}^{2}$ (Potapov, unpublished data).

Sakhalin Island.-In the $19^{\text {th }}$ Century (Suprunenko 1890) and in the first half of the $20^{\text {th }}$ Century, Willow Ptarmigan were abundant and were commercially harvested (Gizenko 1955). The numbers declined from the mid$20^{\text {th }}$ Century, to the extent that the commercial harvest was no longer viable. Currently in the most favorable places, the breeding density of Willow Ptarmigan is 1-2 pairs per $\mathrm{km}^{2}$. Breeding habitats are similar to that of the Amur District - bogs with sparse forest, larch-tree forest with tundra patches and small patches of the Siberian Dwarf Pine, and rarely on gentle slopes with sparse forests. Extensive logging reportedly moved the boundary of the species' range slightly to the south (Voronov et al. 1975), but later this trend was not confirmed (Nechaev 1991).

Forest-steppe Zone.-The most significant changes in the range of Willow Ptarmigan were observed in this zone where the species' southern limit is located. In this zone, the species lives in a wide network of isolated patches of forest, shrubs, and wetlands surrounded by steppe. In the past several decades, the species has shown a tendency for local declines and extinctions in this zone. Although it is not clear what exactly caused the decline, possibilities include human interference, or changes in insect fauna, which play an important role in the diet of chicks, or changes in the vegetation, but it was not global warming. The Willow Ptarmigan populations in this region managed to adapt to climate changes in the past 16,000 years which fluctuated from very cold conditions to hot and then back again to interglacial moderate climates. There are several factors which facilitated these adaptations. Firstly, the changes at the southern fringes of the range were developing for 10,000 years through the Holocene, which makes it possible for natural selection to work. Secondly, this forest-steppe zone, which originated from the mammoth megafauna populated tundra-steppe, was located in the middle of a huge Eurasian continent; so, no matter what the temperature of summer and winter was, and we know that both were swinging up and down, the climate was always continental, as this place is too distant from the oceans. Winters were cold and dry, sometimes with little or no snow, but cold enough for ptarmigan. Thirdly, climate change left the shrub vegetation unchanged as it remained dry. This belt of the southern fringes of the Holocene taiga, stretching from the British Isles to the South Urals, was populated by Willow Ptarmigan which could have survived to this day if humans hadn't taken over the forest-steppe areas by converting them to pasture and arable fields.

Among the interesting adaptations of Willow Ptarmigan facing winters without snow is the complete loss of white winter plumage in Red Grouse (L. l. scoticus) in Scotland and partial loss in Ural-Siberian forest-steppe. It is apparent that the white plumage is retained in the genes, despite the deep local climate change, since 1 in 1000 individuals molt into white plumage in the fall (Hudson pers. comm., Figure 2). This leads us to conclude that throughout the Pleistocene, with its deep swings between glacial (cold) and interglacial (warm) periods, the Willow Ptarmigan did lose and gain again its white winter plumage (Potapov et al. 2003). One of the great illustrations of 


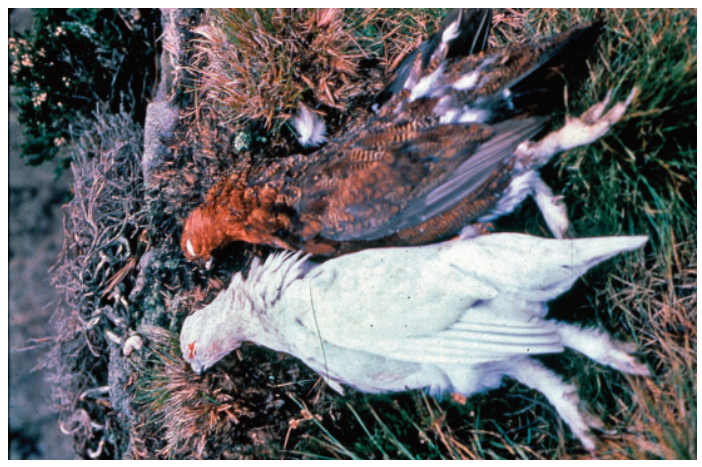

Figure 2. White plumage of Red Grouse and Red Grouse bagged at Scottish Moors. This rare photo shows that the sub-species which has 'lost' white plumage still keeps it in the genes. Note black and white primaries. Photo by Peter Hudson.

this statement was an experiment carried out by A. Barry-Garfoldt in Belgium. He initially introduced Red Grouse to his collection, then later added some Willow Ptarmigan which he imported from Russia. The latter differed from the Red Grouse by molting into white winter plumage, but later lost this winter plumage altogether. This interesting story he told the editor of French "Chasse Perche" magazine (Trutovskaya 1905).

Currently, the distribution of the Forest-Steppe Willow Ptarmigan (L. l. major) is limited in the west by the River Ilek $\left(53^{\circ} 30^{\prime} \mathrm{E}\right)$ and to the east by the Altai foothills (up to $86^{\circ} \mathrm{E}$ ). The southern border of this subspecies is identical to the species' southern border and follows the southern border of the forest-steppe along $52^{\circ} \mathrm{N}$, sometimes going south to $49-50^{\circ} \mathrm{N}$ in places in Kazakhstan (Potapov 1985). Boggy wetlands with lavish grasslands and shrubs are the most preferred habitats here. They also like birch and alder patches. The density is typically $2-4$ pairs per $10 \mathrm{~km}^{2}$, and only in exceptional circumstances reaches $30-40$ pairs per $10 \mathrm{~km}^{2}$. The shrinking of the range at this southern edge has been noted for decades: by 1940 it ceased to exist at the Karakalinsk (49 $\left.30^{\prime} \mathrm{N}, 75^{\circ} 30^{\prime} \mathrm{E}\right)$, Kazakhstan (Kuzmina
1975); by the end of the 1960s it disappeared from several places in the Orenburg District (51 $\left.46^{\prime} \mathrm{N}, 55^{\circ} 05^{\prime} \mathrm{E}\right)$ (Khmelevskiy 1968).

Sub-alpine Zone (Mountains).- The main feature of this zone is the total dominance of shrubs in the vegetation. Such areas cover most of the mountains of south Siberia. The upper altitude limit of this belt is the alpine zone which does not have shrubs. In all mountain systems where this species is present, Willow Ptarmigan exist as isolated populations. At the moment there are two such mountain systems, and each has its own subspecies.

1. Altay-Sayan Mountain System. This region is populated by the Short-billed Willow Ptarmigan (L. l. brevirostris). Its range covers most of the Altay Sayan system from the western border (Ivanovsky Range) 8330' E, Kazakhstan, to the Tunkinskiy Golets $\left(102^{\circ}\right.$ E) and includes all the ranges of the Russian and Mongolian Altay (up to $47^{\circ} \mathrm{N}$ ), and the main ridges of the Sayan, Khangai (including Kuznetskiy Alatau, Tannu Ola and mountains around Hubsugul Lake, and Khentey Mountains). The numbers of ptarmigan are not very high: in Eastern Sayan, 50 pairs per 10 $\mathrm{km}^{2}$ in spring (Izmailov and Tarasov 1968); in Kuznetskiy Alatau, 14 pairs per $10 \mathrm{~km}^{2}$ (Zinoviev 1968); in Central Altay, in the winter seasons of 1940-1950, from 50 to 200 birds per $10 \mathrm{~km}^{2}$, in July 1947,1949 , from 20 to 50 broods per $10 \mathrm{~km}^{2}$ (such concentrations are very rare), and in August from 100 to 120 birds per $10 \mathrm{~km}^{2}$ (Dulkeit 1975).

\section{Mountain Ranges of Eastern Siberia and} Russian Far East. This region includes the mountain ranges of Baikal, Khamar-Daban, Olekmo-Chara highlands, Stanovoy, DzhugDzhur, Yam Alin, Dusse-Alin, and AldanUchur ranges. The breeding habitats here are patches of mountain tundra above the forest line. This region is populated by the Siberian Willow Ptarmigan (L. l. serebrowsky). Moving further northwards, the bond between the ptarmigan and the elevated tundra becomes 


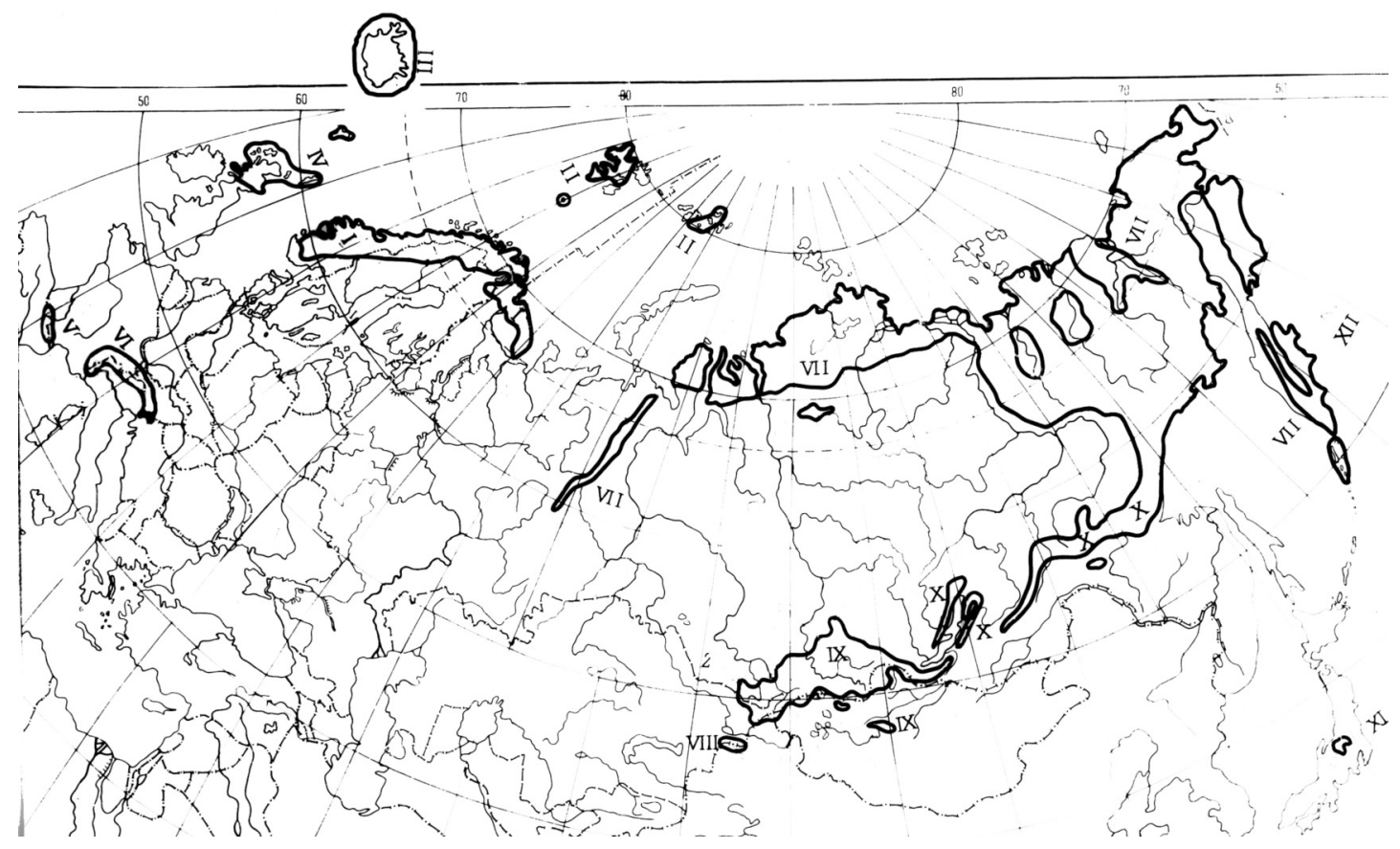

Figure 3. Range of Rock Ptarmigan in Palearctic (from Potapov 1985 with changes and additions). Numbers denote subspecies: I - L. m. muta, II - L. m. hyperboreus, III - L. m. islandorum, IV - L. $m$. milliaisi, V - L. m. pyrenaica, VI - L. m. helveticus, VII - L. m. comensis, VIII - L. m. pleske, IX - L. m. krasheninikowi, X-L. m. macrofynchus, XI - L. m. nadazdae, XII - L. m. transbaicalicus, XIII - L. m. japonicus, XIV - L. m. ridgwayi, XV - L. m. kurilensis.

less powerful. Nevertheless this attachment to the mountains is evident to the northernmost boundary where this subspecies intergrades with the nominate subspecies. The density of this subspecies is comparable to that of the Short-billed Willow Ptarmigan. At the Yablon Range one can find up to 40 broods per $10 \mathrm{~km}^{2}$ (Pavlov 1948). In the Khamar-Daban range the numbers were 13 individuals per $10 \mathrm{~km}^{2}$ in $1958-1959$. In the sub-alpine zone in the winter of 1963, the density was 2-3 individuals per $10 \mathrm{~km}^{2}$ (Izmailov and Pavlov 1975). There are evident, but little studied, vertical seasonal movements; in winter the ptarmigan move from the sub-alpine zone to the bottom of the river valleys.

\section{Rock Ptarmigan (L. muta)}

In contrast to Willow Ptarmigan, Rock Ptarmigan are attached to vertically structured relief: undulating or rolling hills in the polar zone, and elevated mountains in the temperate zone. Information on the species' distribution and abundance is sparse:

- Kola Peninsula: rare, did not see it during transect surveys (Khlebosolov et al. 2007).

- Northern Urals, Dezhkin Kamen': 10 broods per $10 \mathrm{~km}^{2}$ (Danilov 1975).

- Syn' River tributaries, fall 1975: one flock of 25 birds on territory in 400 ha (Potapov 1985). The area suitable for this species in the Urals is c. $13,000 \mathrm{~km}^{2}$, which gives potential numbers of 40,000 - 50, 000 individuals. 
Table 5. Estimates of Willow Ptarmigan for the winter 2006 (Potapov, unpublished data) and estimates given for the same territory by the ARWS (Mezhnev 2002).

\begin{tabular}{lcr}
\hline Territory & 2006, Potapov, unpublished & 2001, Mezhnev 2002 \\
\hline Karelia & 300,000 & 274,000 \\
Leningrad and Novgorod districts & 10,000 & $(50,900+18,600)$ \\
Pskov District & 500 & 1500 \\
\hline
\end{tabular}

- Putoran Plateau: No density data. Considered to be rare, but not so rare in the central and western parts of the Plateau (Romanov 2004).

- Yamal, Gydan, Taimyr: No precise data available. It was mentioned that the total numbers were several times lower than that of Willow Ptarmigan. From the past commercial harvest in the 1970s, it was known that in the annual bag of 150,000 ptarmigan, Rock Ptarmigan constituted only 10-15\% (Pavlov 1975).

- Yakutia: No accurate counts. It was known that in the Kolyma-Alazeya plain the numbers of Rock Ptarmigan were lower than Willow Ptarmigan by 40-50 times; in the Khroma-Indigurka plain they were 100 times lower (Perfiliev 1975).

- Far-East, Okhotsko-Kolyma Highlands: In 1963, 10-30 pairs were recorded per $10 \mathrm{~km}^{2}$ of suitable habitat (Perfilev 1975).

- Koryak Highlands: In 1961, 10-30 pairs were recorded per $10 \mathrm{~km}^{2}$ of suitable habitat (Perfilev 1975).

- Kamchatka: In 1967 in the Parapol depression (plain tundra), up to 20 pairs per $10 \mathrm{~km}^{2}$ were recorded (Lobkov 1986). Five broods were recorded in $1 \mathrm{~km}^{2}$ (Voronov 1968). Along the Kambalnaya River, on slopes above $400 \mathrm{~m}$ asl, the density was 40-60 individuals per $10 \mathrm{~km}^{2}$ (Gizenko 1968).

- Commander Islands: In 1960, 50-100 pairs per $10 \mathrm{~km}^{2}$ were recorded. Total numbers on the Beringa and Medniy Islands were estimated at 9,000 to 10,500 birds (Marakov 1962).
- Kuril Islands: The species was common here. Maximum density up to 100 birds per 10 $\mathrm{km}^{2}$. On the islands of Paramushir and Shumshu in 1967 there were 20,000 birds wintering (Velizhanin 1968). On Paramushir in 1960, 3-4 broods were recorded on a $1 \mathrm{~km}$ transect (Voronov 1968).

\section{TOTAL NUMBER OF PTARMIGAN IN RUSSIA}

The ARWS estimated the total numbers of Willow and Rock Ptarmigan (combined) for the years of 2000, 2001, and 2002 respectively as $34965.9,18705.4$ and 10471.3 thousand individuals. We suspect that these are overestimates. Compared to our data for Willow Ptarmigan that we estimated for the Karelia, Pskov, Novgorod, and Leningrad Districts (Table 5), the official statistics provide a more or less accurate estimate for the districts with a high density of ptarmigan, whereas in the districts with moderate or low density of birds, the official figures tend to overestimate the real numbers. Evidently, the official counts are too optimistic for overall counts, but they are better than nothing.

\section{ACKNOWLEDGMENTS}

We thank the Trust for Mutual Understanding and The Peregine Fund for making the attendance of the conference possible for one of the authors, and Nick Potapov for help with language translation. 


\section{Literature Cited}

AndReEv, A. V. 1988. The ten year cycle of the Willow Grouse of lower Kolyma. Oecologia 76:261-267.

BoCHENSKI, Z. 1991. Pliocene grouse of the genus Lagopus from Poland. Acta Zoologica Cracoviensia 34:563-577.

Boev, Z. 1995. Middle Villafranchian birds from Varschets (Western Balkan RangeBulgaria). Courier Forschungsinstitut Senckenberg 181:259-269.

DANILOV, N. N. 1975. Urals and trans-Urals. Pages 59-82 in S. V. Kirikov (Ed.). Tetraonid Birds. Nauka Publishers, Moscow, Russia (in Russian).

Dulkeit, G. D. 1975. Altay and Sayan. Pages 83-99 in S. V. Kirikov (Ed.). Tetraonid birds. Nauka Publishers, Moscow, Russia. (In Russian)

Fedosenko, A. K., And V. G. Belozerov. 1968. Material on distribution and numbers of Tetraonid birds in Evenkia. Pages 80-81 in S. V. Kirikov and O. N. Shubnikova (Eds.). Resources of the Tetraonid Birds in the USSR. Nauka Publishers, Moscow, Russia (in Russian).

Fetisov, A., Yu. Ivanov, And A. Leonteva. 1999. Results of Willow Ptarmigan surveys in the Pskov District in 1997-98. Pages 8789 in S. Nikonov (Ed.). Proceedings of International Conference: Problems of Ecology and Regional Policies in NorthEast Russia and Adjacent Territories. Pskov Branch of the Russian Geographical Society, Pskov, Russia (in Russian).

GizenKo, A. I. 1955. Birds of the Sakhalin District. Nauka Publishers, USSR Academy of Sciences, Moscow-Leningrad, Russia (in Russian).

GizENKo, A. I. 1968. The biology and numbers of Willow and Rock Ptarmigan in Kamchatka. Pages 12-13 in S. V. Kirikov and O. N. Shubnikova (Eds.). Resources of the Tetraonid Birds in the USSR. Nauka Publishers, Moscow, Russia (in Russian).

Gyngazov, A. M., AND N. G. Shubin. 1968. On the distribution and numbers of grouse in Western Siberia. Pages 13-15 in S. V. Kirikov and O. N. Shubnikova (Eds.). Resources of the Tetraonid Birds in the USSR. Nauka Publishers, Moscow, Russia (in Russian).

IsAEV, A. P. 2006. Method of aerial counts of Tetraonid birds in Yakutia. In N. Ilyinskih (Ed.). Natural History and Humanism: Tomsk. Tomsk City Publishers, Russia (in Russian).

IsAEV, A. P. 2011. Change in ptarmigan numbers in Yakutia. In R. T. Watson, T. J. Cade, M. Fuller, G. Hunt, and E. Potapov (Eds.). Gyrfalcons and Ptarmigan in a Changing World. The Peregrine Fund, Boise, Idaho, USA. http://dx .doi.org/10.4080/gpcw.2011. 0304

IVANOVSKiY, V. V., AND V. T. KovalionoK. 2002. Breeding of mid-Russian Willow Ptarmigan (Lagopus lagopus rossicus) in Belorussia. Subbuteo (Minsk) 5 (1):47-48 (in Russian).

IVANTER, E. V. 1974. Western Capercaillie and Willow Ptarmigan in Karelia. Ornitologia 2:206-226 (in Russian).

IzMailov, I. V., AND M. P. PAVlov. 1975. PreBaikalie and Transbaikal. Pages 100-112 in S. V. Kirikov (Ed.). Tetraonid Birds. Nauka Publishers, Moscow, Russia (in Russian)

IzMaIlov, I.V., AND M. P. TARASOv. 1968. Tetraonid birds in pre-Baikal and Tranbaikal. Pages 29-31 in S. V. Kirikov and O. N. Shubnikova (Eds.). Resources of the Tetraonid Birds in the USSR. Nauka Publishers, Moscow, Russia (in Russian).

KARPOVICH, V. I. 1963. Counting numbers of tetraonid birds on transects in vast areas. Pages 12-19 in A. N. Formozov and Yu. A. Isakov (Eds.). Organization and Methods of Counts of Birds and Harmful Rodents. USSR Academy of Sciences, Institute of Geography, Moscow, Russia (in Russian). Khlebosolov, E. I., O. A. Makarova, O. A. Khlebosolova, and N. V. Polikarpova. 2007. Birds of Pasvik. "Golos Gubernii" Publishers, Ryazan, Russia (in Russian). KhMelevskiY, A. 1968. Geography and numbers of Tetraonid birds in the Orenburg Dis- 
trict. Pages 81-82 in S. V. Kirikov and O. N. Shubnikova (Eds.). Resources of the Tetraonid Birds in the USSR. Nauka Publishers, Moscow, Russia (in Russian).

KishinskiY, A. A. 1975. North of Far East. Pages 136-156 in S. V. Kirikov (Ed.). Tetraonid Birds. Nauka Publishers, Moscow, Russia (in Russian).

Kondratiev, A. V. 2006. Technical Report to ECORA. http://www.noruec.com/innhold/ andre_samarbeidsomraader/ecora/biodiversity/kondratyev_ecora_2006.pdf

Korshunova, E., AND E. Korshunov. 2010. On the propagation and reintroduction of Willow Ptarmigan in Kerzhenteskiy State Nature Reserve. Page 162 in E. N. Kurochkin and A. V. Davygora (Eds.). Ornithology in Northern Eurasia. Proceedings of the XIII International Ornithological Conference of Northern Eurasia, Orenburg Pedagogical University Publishers, Orenburg, Russia.

KrechmaR, A. V. 1966. Birds of Western Taimir. Pages 185-312 in A. I. Ivanov (Ed.). Proceedings of the Zoological Institute of the Academy of Sciences of the USSR, vol. 39. Nauka Press, Leningrad, Russia (in Russian).

KurvitTs, T., E. KuZNETSOV, AND T. LARSEN. 2009. An Integrated Ecosystem Management Approach to Conserve Biodiversity. CAFF Technical Report No.19-ECORA Annual Report. CAFF, Akureyri, Iceland.

KuZMinA, M.A. 1975. Kazakhstan. Pages 323338 in S. V. Kirikov (Ed.). Tetraonid Birds. Nauka Publishers, Moscow, Russia (in Russian).

Kuzyakin, V. A., N. G. Chelintsev, And I. K. LOMANOV. 1990. Methods for organizing, conducting, and processing winter transect data for game animals in the Russian Federation (with algorithms of extrapolation). Glavokhota of the Russian Federation (in Russian).

LobKov, E. G. 1986. Breeding birds of Kamchatka. Far Eastern Branch of the USSR Academy of Sciences, Vladivostok, Russia (in Russian).
MARAKOV, S. V. 1962. Commander Islands Rock Ptarmigan and its harvest. In Rationalization of Hunting Harvest. Moscow 10:88-90.

MASLOV, V. I. 1972. Radioecology of grouse in the biogeocenoses of the thorium region. Pages 191-215 in I. N. Verkhovskaya (Ed.). Radioecological investigations in natural biogeocenoses. Nauka Publishers, Moscow, Russia.

Menzbier, M. A. 1902. Game birds of European Russia and the Caucasus, vol. 2. Moscow, Russia.

Mezhnev, A. P. 2002. Resources of wintering Tetraonid birds and their use at the edge of the millennium. Pages 311-326 in Proceedings of the Conference: Questions of modern Game sciences. State Department "Centrokhotcontrol" (Center of control for hunting), Moscow, Russia (in Russian).

Mezhnev, A. V. 2000. Capercaillie, Blackgrouse, ptarmigan. Current status of game in Russian Federation. Information-analytical material. In Game Animals in Russia: Biology, Conservation, Resources and Rational Use. State Department Centrokhotcontrol 2:109-110 (in Russian).

MikheEv, A. V. 1948. Willow Ptarmigan. State Department of Nature Reserves, Moscow Russia (in Russian).

Mikheev, A. V. 1952. Family Tetraonidae. Pages 10-246 in G. P. Dementiev and N.A. Gladkov (Eds.). Birds of the Soviet Union, vol. 4. Sovetskaya Nauka, Moscow, Russia.

Nechaev, V. A. 1991. Birds of Sakhalin Island. Far Eastern Branch of the USSR Academy of Sciences, Vladivostok, Russia (in Russian).

Pavlov, E. I. 1948. Birds and Mammals of the Chita District. Chitaizdat Publishers, Chita, Russia (in Russian).

Pavlov, B. M. 1975. Taimyr Peninsula. Pages 17-26 in S. V. Kirikov (Ed.). Tetraonid Birds. Nauka Publishers, Moscow, Russia (in Russian).

Peel, M. C., B. L. Finlayson, and T. A. McMahon. 2007. Updated world map of the Köppen-Geiger climate classification. 
Hydrology and Earth System Sciences 11:1633-1644.

PerfiLIEV, V. I. 1975. Yakutia. Pages 113-115 in S. V. Kirikov (Ed.). Tetraonid Birds. Nauka Publishers, Moscow, Russia (in Russian).

POTAPOV, R. L. 1985. Order Galliformes, family Tetraonidae. In Fauna of the USSR, new series 133. Nauka, Leningrad, Russia (in Russian).

Potapov, R. L. 2004. Gray Partridge, Corncrake, and Middle-Russian Willow Ptarmigan. Pages 119-121 in G. A. Noskov (Ed.). Red Data Book of Nature of St. Petersburg, "Professional" Publishers, St. Petersburg, Russia (in Russian).

Potapov, R. L., O. R. Potapova, and E. A. Pavlova. 2003. The genus Lagopus Brisson, 1760: Taxonomy, paleontological dates and evolution. Proceedings of the Zoological Institute of the Russian Academy of Sciences 299:100-120.

RED DATA BOOK OF BYElORUSSIA. 2006. http://redbook.minpriroda.by/animals .html

Rodionov, M. A. 1969. On the biology of Willow Ptarmigan in the Leningrad District. Annual book of the Society of Natural History, Academy of Sciences of the Estonian SSR, 59:57-78 (in Russian).

Romanov, A. A. 2004. Avifauna of the Putorano Plateau. Pages 113-229 in A. A. Romanov (Ed.). Vertebrate fauna of the Putorana Plateau. Russian Academy of Agricultural Sciences, Moscow, Russia (in Russian).

Romanov, A. N. 1975. Northeast of the Russian Plain. Pages 45-58 in S. V. Kirikov (Ed.). Tetraonid Birds. Nauka Publishers, Moscow, Russia (in Russian).

Romanov, Yu. M., AND M. V. Kozlova. 2001. Middle-Russian Willow Grouse. Pages 458-459 in D. S. Pavlov, L. N. Mazin, V. V. Rozhnov, and V. E. Flint (Eds.). Krasnaya kniga Rossiyskoy Federatsii (Zhivotnye) [Red Data Book of the Russian Federation (Animals)]. AST and Astrel' Publishers. Aginskoye and Balashikha, Russia.
Sabaneev, L. P. 1902. Hunting calendar. Reference book on gun and canine hunters. Zoological Museum Edition, Supplement to the "Nature and Hunting" Magazine, ILXXXYIII, 1-4 November: 5-132, December: 133-140 (in Russian).

Sevastianov, G. N. 1974. Counting of tetraonid birds in the subzone of the middle taiga of the Komi Autonomous Republic. Ornitologia 11:339-346 (in Russian).

Skrobov, V. D. 1968. On the Willow Ptarmigan of the Bolshezemelskaya Tundra. Pages 72-74 in S. V. Kirikov and O. N. Shubnikova (Eds.). Resources of the Tetraonid Birds in the USSR. Nauka Publishers, Moscow, Russia (in Russian).

Soloviev, D. K. 1927. Willow Ptarmigan in the Pechora region. Ural Hunter 8-9: 2-24 (in Russian).

STEWART, J. R. 2000. Intraspecific variation in modern and quaternary European Lagopus. Smithsonian Contributions to Paleobiology 89:159-168.

SUPRUNENKO, P. I. 1890. Fauna of vertebrates of the Sakhalin Island. Catalogue of the International Prison Exhibition, St. Petersburg, Russia (in Russian).

SYroechKovski, E. E., AND E. V. RogacheVA. 1968. Zonal distribution and the numbers of Willow Ptarmigan in the Yenisey Taiga and forest-tundra. Pages 77-78 in S. V. Kirikov and O. N. Shubnikova (Eds.). Resources of the Tetraonid Birds in the USSR. Nauka Publishers, Moscow, Russia (In Russian).

TARAsov V. 1995. Ecology of Willow Ptarmigan in the Northen Yamal. Pages 152-153 in V. K. Ryabitsev (Ed.). Proceedings of the Conference: Mechanisms of Maintenance of Biodiversity (in Russian).

Trutovskaya, N. 1905. Propagation of Scotish Grouse and Russian Willow Grouse in Belgium. Psovaya and Ruzheinaya Okhota 4 (1):5-7 (in Russian).

UsPENSKIY, S. M. 1965. Data on the avifauna of the northern Anabar tundras. Pages 6397 in N. A. Gladkov (Ed.). Archives of the Zoological Museum of Moscow Univer- 
sity, vol. 9. Moscow University Press, Moscow Russia (in Russian).

VARTAPETOV, L. G. 1998. Birds of the Northern Taiga of the Western Siberian Plain. Nauka Publishers, Novosibirsk, Russia (in Russian).

Velizhanin, A. G. 1968. On the Rock Ptarmigan of the Kuril Islands. Pages 6-7 in S. V. Kirikov and O. N. Shubnikova (Eds.). Resources of the Tetraonid Birds in the USSR. Nauka Publishers, Moscow, Russia (in Russian).

Voronin, R. N. 1995. Willow Grouse. In R. L. Potapov (Ed.). Fauna of the North-East of Russia. Nauka Publishers, St. Petersburg (in Russian)

Voronov, V. G. 1968. Distribution and density of grouse in the south of the Kamchatka Peninsula and northern Kuril islands. Pages 10-11 in S. V. Kirikov and O. N. Shubnikova (Eds.). Resources of the Tetraonid Birds in the USSR. Nauka Publishers, Moscow, Russia (in Russian).

Voronov, V. G, G. A. Voronov, AND V. P. BShIVTSEV. 1975. Sakhalin and Kuril islands. Pages 251-258 in S. V. Kirikov (Ed.). Tetraonid Birds. Nauka Publishers, Moscow, Russia (in Russian).

ZINOVIEV, L. I. 1968. Distribution and numbers of the Willow Ptarmigan in Kuznetskiy Alatau. Page 23 in S. V. Kirikov and O. N. Shubnikova (Eds.). Resources of the Tetraonid Birds in the USSR. Nauka Publishers, Moscow, Russia (in Russian). 